\title{
Fulminant liver failure with necrotizing foci in the liver, spleen and lymph nodes in celiac disease due to malignant lymphoma
}

\author{
HUGH JAMES FREEMAN MD
}

HJ FreEman. Fulminant liver failure with necrotizing foci in the liver, spleen and lymph nodes in celiac disease due to malignant lymphoma. Can J Gastroenterol 1996;10(4):225-229. A 65-yearold female with celiac disease developed cholestatic jaundice and fatal liver failure. Investigations revealed widespread necrotic foci in the liver, spleen and mesenteric lymph nodes, changes reminiscent of the mesenteric lymph node cavitation syndrome, which is known to complicate celiac disease. In addition, malignant lymphoid cells were present infiltrating hepatic sinusoids, lymph nodes and spleen. These features are typical of hepatosplenic lymphoma, a rare type of peripheral $\mathrm{T}$ cell lymphoma with $\mathrm{T}$ cell receptor rearrangement. Lymphorecticular malignancy complicating celiac disease may present with fulminant liver disease.

Key Words: Celiac disease, Delta-gamma T cell receptor, Hepatosplenic T cell lymphoma, Liver failure, Malignant lymphoma, Mesenteric lymph node cavitation syndrome, Mortality

\author{
Insuffisance hépatique fulminante avec foyers \\ nécrosants au foie, à la rate et aux ganglions \\ lymphatiques associée à la maladie cæliaque due à \\ un lymphome malin
}

RÉSUMÉ : Une patiente de 65 ans atteinte de maladie cæliaque a présenté un ulcère cholostatique et une insuffisance hépatique fatale. Des épreuves diagnostiques ont révélé la présence de foyers nécrosants répandus au foie, à la rate et aux ganglions lymphatiques mésentériques, anomalies évocatrices d'un syndrome d'excavation des ganglions lymphatiques mésentériques qui complique la maladie cæliaque. De plus, des cellules lymphoïdes malignes étaient présentes et infiltraient les sinusoïdes hépatiques, les ganglions lymphatiques et la rate. Ces caractéristiques sont typiques d'un lymphome hépatosplénique, un rare type de lymphome à cellules $T$ périphériques avec réorganisation des récepteurs des cellules $T$. La néoplasie lymphoréticulaire qui complique la maladie cæliaque peut être présente lors d'une maladie hépatique fulminante.
$\mathrm{H}$ epatic and biliary tract changes have been described in celiac disease, including a variety of chronic cholestatic disorders (1-3). Indeed, the coexistence of celiac disease and primary biliary cirrhosis with antimitochondrial antibodies has been described in more than 20 patients $(4,5)$, and rare reports of sclerosing cholangitis in celiac disease $(6,7)$ have been noted. In one report $(7)$, lymphocytic infiltration of bile duct epithelium was observed, similar to the features seen in both lymphocytic gastritis and lymphocytic colitis, previously reported in celiac disease $(8,9)$. Finally, sclerosing cholangitis may be complicated by lymphoma (10), also known to occur with increased frequency in patients with celiac disease (11-13), especially if diagnosis is first established after age 60 years (14).

Department of Medicine (Gastroenterology), University of British Columbia, Vancouver, British Columbia

Correspondence and reprints: Dr Hugh Freeman, ACU F-137, Gastroenterology, Vancouver Hospital (UBC Site), 2211 Wesbrook Mall,

Vancouver, British Columbia V6T 1W5. Telephone 604-822-7216, fax 604-822-7236

Received for publication June 9, 1995. Accepted August 23, 1995 


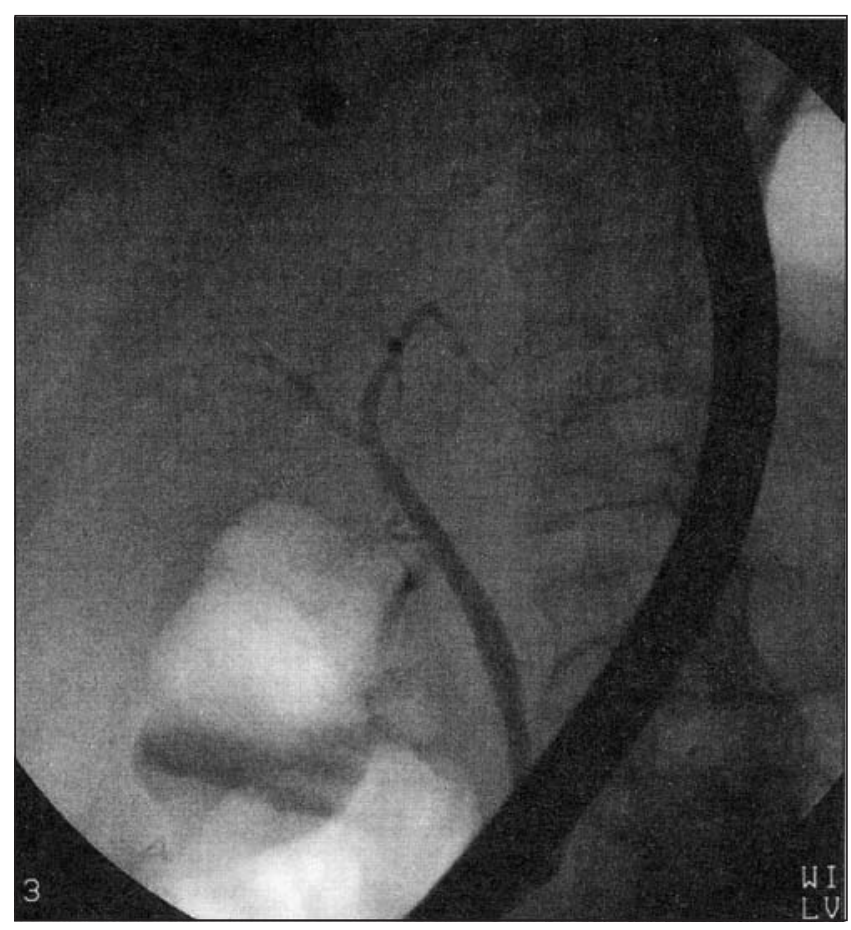

Figure 1) Retrograde cholangiogram showing minimal attenuation of the intrahepatic biliary ductal system

The French literature (15-17) has also described a rare syndrome in celiac disease consisting of hyposplenism and cavitation necrosis of mesenteric lymph nodes. This disorder may also be complicated by small intestinal lymphoma (18). Necrotizing cholangitis or necrotic hepatic foci occur with ascending biliary tract and hematogenous infections, human immunodeficiency virus (HIV)-related immune deficiency syndromes, chemical toxins, therapeutic drugs and the toxic shock syndrome (19). In addition, a previous report (20) noted randomly scattered 'punched-out' foci of hepatic necrosis in patients with lymphoreticular malignancies causing fulminant hepatic disease.

In this report, a patient with celiac disease and hyposplenism is described with multiple necrotic foci in the liver, spleen and mesenteric lymph nodes. Despite extensive studies to exclude an occult infection or neoplasm, including lymphoma, fulminant hepatic disease developed. Postmortem investigations revealed widespread sinusoidal hepatic infiltration with a hepatosplenic lymphoma, a rare peripheral $T$ cell lymphoma with rearrangement of the deltagamma $\mathrm{T}$ cell receptor. Lymphoreticular malignancies presenting with fulminant hepatic disease may complicate celiac disease.

\section{CASE PRESENTATION}

In July 1994 a 65-year-old female developed diarrhea which consisted of four to six poorly formed, pale stools daily associated with fatigue, anorexia and weight loss of $18 \mathrm{~kg}$. There was marked muscle wasting present but no fever or jaundice. Investigations in her community hospital included small intestinal biopsies that showed a severe 'flat' mucosal lesion, typical of untreated celiac disease (21). Barium radiologic studies of the upper and lower gastrointestinal tracts, including a small bowel enteroclysis, were normal. Fecal parasite studies and cultures as well as a Clostridium difficile toxin assay were negative. She was treated with a gluten-free diet. By October 1994, the diarrhea resolved and her weight increased $9 \mathrm{~kg}$.

During the next six weeks, diarrhea recurred with weight loss of $5 \mathrm{~kg}$. She became anemic with a hemoglobin of $82 \mathrm{~g} / \mathrm{L}$ (normal 115 to 160) and developed hypoalbuminemia (20 g/L, normal 35 to 52$)$ and hypocalcemia $(1.78 \mathrm{mmol} / \mathrm{L}$, normal 2.10 to 2.60). Liver chemistry tests (aspartate aminotransferase [AST], alanine aminotransferase [ALT], bilirubin) were normal, except for an alkaline phosphatase [ALP] of $211 \mathrm{U} / \mathrm{L}$ (normal less than 125). Abdominal ultrasound and computed tomographic (CT) examination were normal with no dilated bile ducts, enlarged liver or lymphadenopathy. Because of her deteriorating clinical state, however, lymphoma was suspected and she was transferred for further evaluation.

Scleral icterus was now present in addition to muscle wasting. Liver, spleen and lymph nodes were not enlarged. There were no stigmata of chronic liver disease. Laboratory studies revealed a hemoglobin of $91 \mathrm{~g} / \mathrm{L}$ (normal 120 to 160) with normal red blood cell indexes but a blood smear showed Howell-Jolly bodies, typical of hyposplenism. White blood cell count and platelets, international normalized ratio (INR), serum carotene, iron, folic acid and vitamin $\mathrm{B}_{12}$ levels were normal. Liver chemistry tests were abnormal: serum bilirubin was $157 \mu \mathrm{mol} / \mathrm{L}$ (normal 2 to 23), ALP was $438 \mathrm{U} / \mathrm{L}$ (normal 30 to 115), AST was $118 \mathrm{U} / \mathrm{L}$ (normal 5 to 47) and ALT was $95 \mathrm{U} / \mathrm{L}$ (normal 10 to 60). Serum immunoglobulins, amylase, cholesterol, triglycerides and thyroid function studies were normal.

Serological studies for hepatitis A virus, hepatitis B virus, hepatitis $\mathrm{C}$ virus, cytomegalovirus (CMV), respiratory viruses (including Coxsackie viruses and adenovirus), herpes simplex viruses (HSV), HIV and Ebstein-Barr virus were negative. Cultures of blood, bone marrow, urine, sputum, pleural and ascitic fluids were negative. Perinuclear antineutrophil cytoplasmic antibodies, antinuclear antibodies and antimitochondrial antibodies were negative. Additional small bowel biopsies on a gluten-free diet showed the reappearance of villi, consistent with treated celiac disease (21). Endoscopic studies of the upper and lower gastrointestinal tracts were normal while gastric and colonic biopsies revealed epithelial lymphocytosis $(8,9)$. Abdominal ultrasound and CT showed a small pleural effusion and ascites. Endoscopic retrograde cholangiogram revealed slightly attenuated intrahepatic bile ducts (Figure 1).

Over the next 16 days the patient's liver function continued to deteriorate; INR increased to 2.2 (normal 1.0), bilirubin to $227 \mu \mathrm{mol} / \mathrm{L}$ and ALP to $1343 \mathrm{U} / \mathrm{L}$. Transjugular liver biopsies revealed focal areas of necrosis but viral, bacterial and fungal cultures of the liver biopsy were negative. Some lymphoid cells were seen in hepatic sinusoids. Immunocytochemical studies of the liver for infectious agents (ie, CMV, 
HSV) were negative (22). She was empirically treated with broad spectrum antibiotics, but died after her clinical course became complicated by hepatorenal syndrome and encephalopathy.

Postmortem studies showed a grossly normal liver (Figure 2) but microscopic examination (Figure 3) revealed widespread sinusoidal infiltration with atypical neoplastic lymphoid cells. Some sinusoids had clusters of lymphoid cells while others were infiltrated with individual or single files of lymphoid cells (Figure 4) . Similar lymphoid cell infiltrates were seen in the spleen and lymph nodes. In addition, numerous well demarcated microscopic necrotic foci were present in the liver (Figure 5) as well as in spleen and lymph nodes; however, extensive postmortem cultures of the liver, spleen and lymph nodes were negative. Necrotic foci were randomly located in the liver, with some in periportal or pericentral areas; some, but not all, necrotic foci appeared to be related to malignant cells. Lymphoma was not detected in the stomach or intestinal tract.

Immunophenotyping of the atypical lymphoid cell infiltrate was positive for $\mathrm{CD} 3$, a marker of $\mathrm{T}$ cell differentiation. The cells also failed to express L26, a B cell marker, myelo-

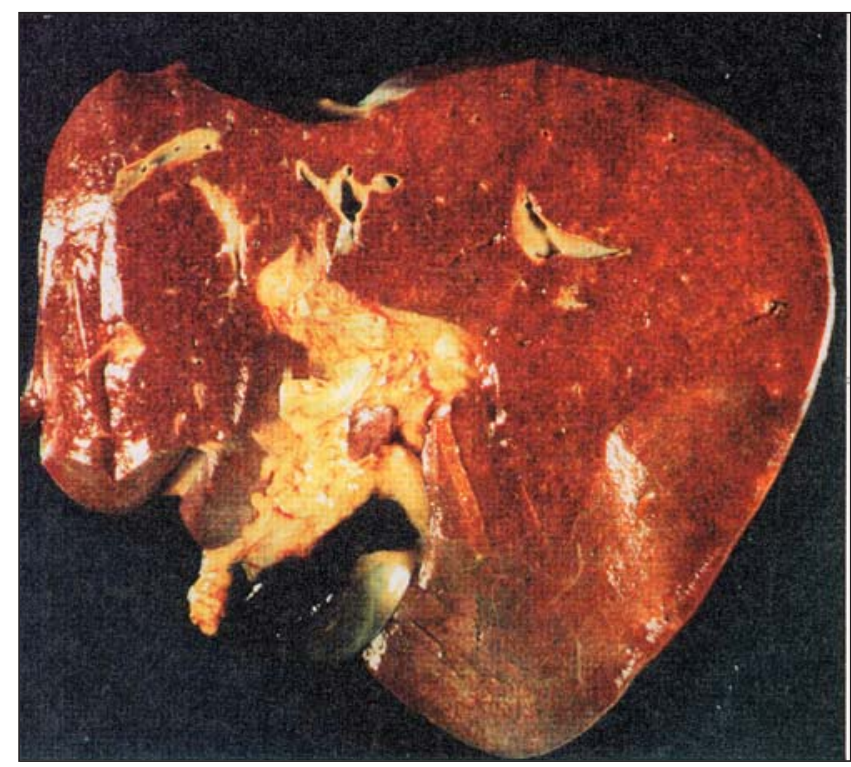

Figure 2) Liver showing essentially normal gross appearance in the postmortem specimen. Nodules or other macroscopic features of malignant infiltration were not detected. Microbiological studies were negative
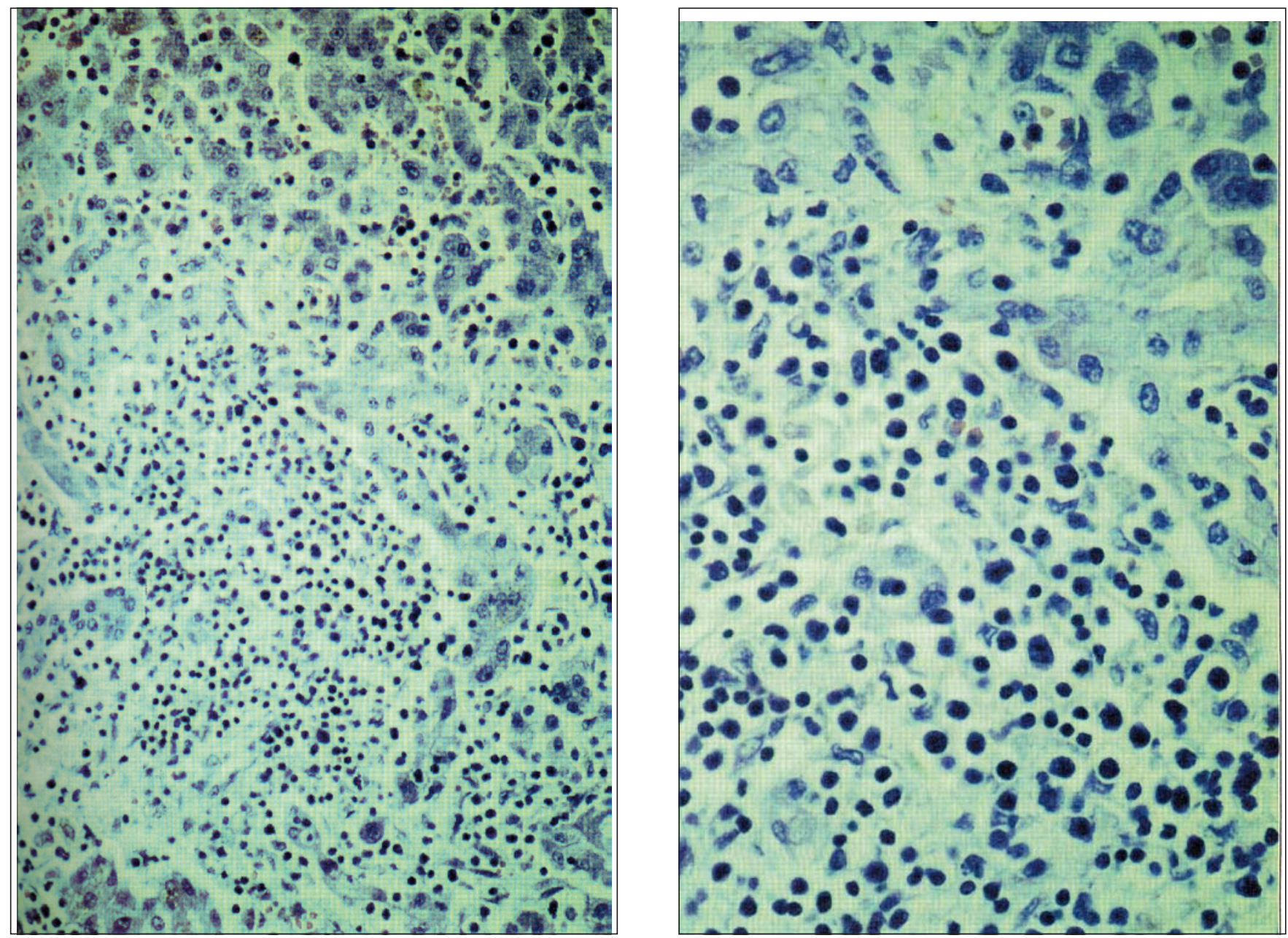

Figure 3) Left Extensive infiltration with aggregates of liver neoplastic lymphoid cells. In some hepatic sinusoids, only individual lymphoid cells are present. Some hepatocytes appear atrophic; in other areas, hepatocellular coagulative necrosis is evident (hematoxylin and eosin X99); Right Same field as in Left with atypical pleomorphic collection of lymphoreticular cells (hematoxylin and eosin x248) 

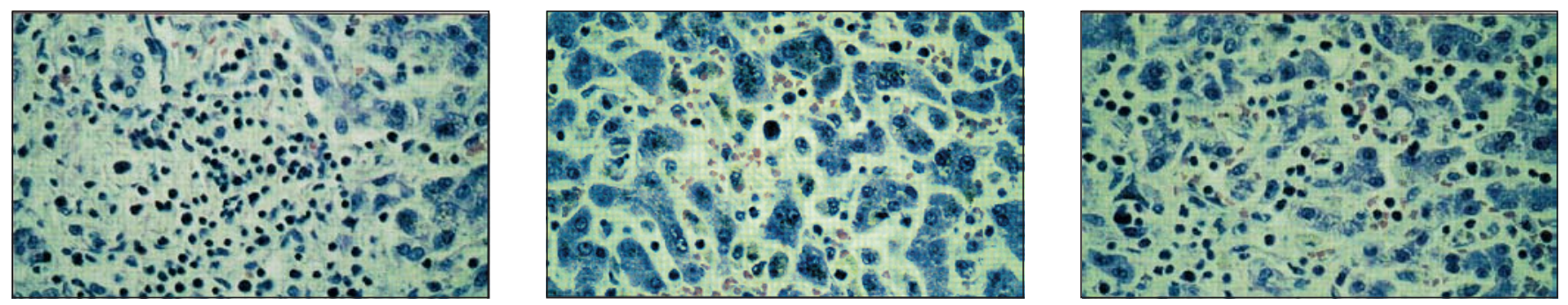

Figure 4) Postmortem histological studies of the liver (hematoxylin and eosin x107). Left Periportal aggregate of lymphoid cells, some with bizarre nuclei; limiting plate is disrupted; Centre Within hepatic sinusoids, atypical lymphoid cells are present either alone or lined up as beaded strings; Right Large, bizarre lymphoid cell in hepatic sinusoid
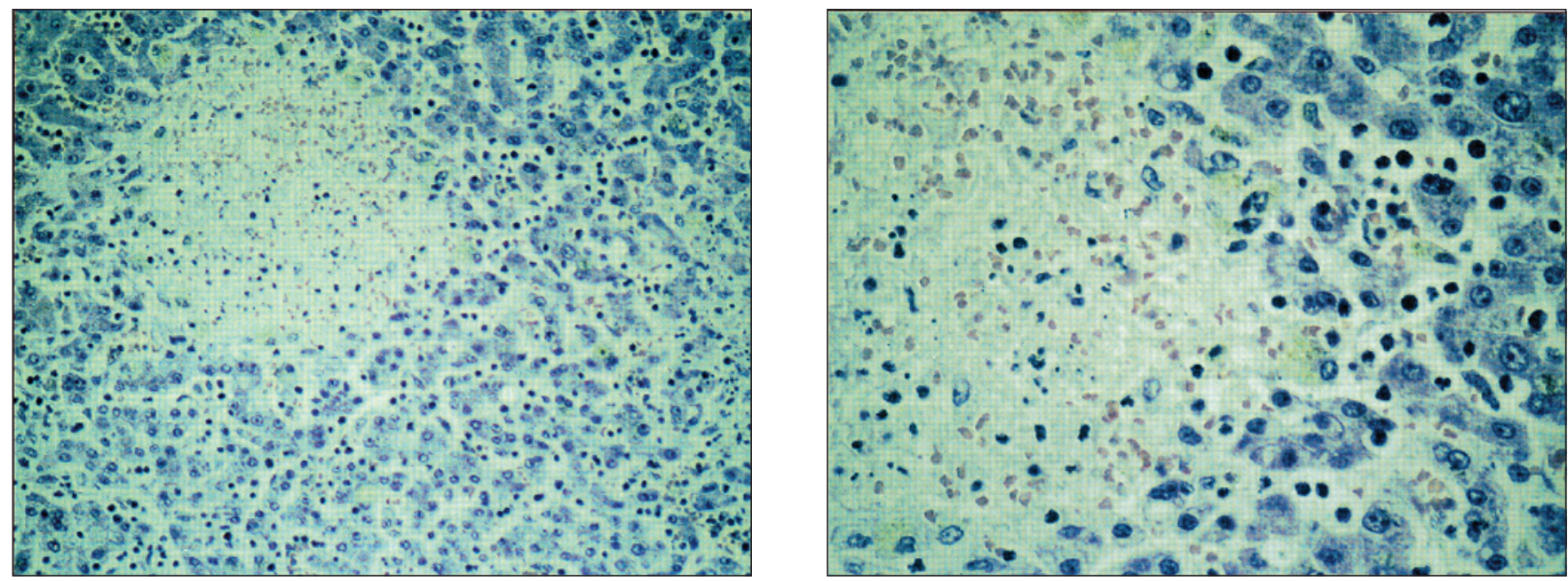

Figure 5) Left Necrotizing 'punched-out' foci in liver with sparse lymphoid cellular content; in contrast, hepatic sinusoids contain numerous atypical lymphoid cells (hematoxylin and eosin x63); Right Same field as in Left with focal area of necrosis and adjacent liver cell sinusoids infiltrated with atypical lymphoid cells (hematoxylin and eosin $x 157$ )

peroxidase and CD-34, an antigen expressed by myeloid and lymphoid blast cells. These findings were typical of hepatosplenic lymphoma, a rare type of $\mathrm{T}$ cell lymphoma with $\mathrm{T}$ cell receptor rearrangement $(23,24)$.

\section{DISCUSSION}

The fulminant cholestatic syndrome in this patient with biopsy-defined celiac disease proved to be due to malignant lymphoma localized to the liver, spleen and mesenteric lymph nodes. The clinical behaviour, morphology, immunophenotype and localization of this lymphoma are typical of a lymphoid neoplasm currently classified as a hepatosplenic lymphoma, a rare type of peripheral $\mathrm{T}$ cell lymphoma with rearrangement of the gamma-delta $T$ cell receptor $(23,24)$. In the presented patient, the aggressive clinical course was typical of this variant $(24,25)$, while its morphology and immunophenotype were distinct with small and large atypical $\mathrm{T}$ cells (23). This finding contrasts with the description of intestinal $\mathrm{T}$ cell lymphoma (ie, enteropathy associated $\mathrm{T}$ cell lymphoma) (26), the form of peripheral $\mathrm{T}$ cell lymphoma usually detected in celiac disease or gluten-sensitive enteropathy (11-14).

In patients with celiac disease and lymphoma, enteropathy-associated $\mathrm{T}$ cell lymphoma usually has an aggressive clinical course, often with death due to multifocal intestinal ulceration and perforation. Hepatic involvement is usually limited and overshadowed by the clinical course of the intestinal disease. In contrast, the presented patient had fulminant hepatic disease and failure due to widespread hepatic involvement with this unusual lymphoid neoplasm. In general, most patients with lymphoreticular malignancies manifest the disease primarily in the blood or lymphoid tissues. Although evidence for liver dysfunction may be present in lymphoma, only rarely does hepatic or biliary tract disease dominate the patient's clinical presentation (20,27-29). Premortem diagnosis of lymphoid neoplasm involving the liver is notoriously difficult (20). This parallels previous observations with intestinal lymphoma complicating celiac disease; in one patient, almost 100 small bowel biopsies were required to diagnose lymphoma (18). In the presented case, despite a strong clinical suspicion, transjugular liver biopsies failed to show definite lymphoma, and only after postmortem examination was lymphoma recognized. In part, this likely reflects limited experience with the detection of this rare variant of lymphoma in premortem liver biopsies as well as limitations related to liver biopsy sampling. Because of its rapid clinical course, the opportunity to diagnose lymphoma in the liver is also limited because most patients die within weeks of clinical presentation $(27,28)$.

The hepatic disease in our patient had some other fea- 
tures not previously reported elsewhere in celiac disease, especially in those with coexistent liver disease or splenic hypofunction (29-31). The detection of multiple punchedout necrotizing hepatic foci with necrosis in other lymphoreticular sites, including the spleen and mesenteric lymph nodes, was intriguing. Despite extensive microbiological and immunohistochemical studies, a viral, bacterial or fungal cause could not be defined. These necrotic changes were reminiscent of pathological features in the mesenteric lymph node cavitation syndrome (15-17), and subsequently observed in celiac disease complicated by extensive small bowel lymphoma (18). In this unusual condition, pathological studies have shown multiple areas of necrotizing cavitation in reticuloendothelial tissues; this disorder is usually accompanied by splenic hypofunction, including changes seen in this patient's circulating red blood cells, eg, HowellJolly bodies. Although hepatic necrosis has not been described in these patients, the pathogenesis may be similar and related to an occult but rapidly growing lymphoid neoplasm, often with disturbed glucose homeostasis, altered electrolyte-acid-base status and hyperlactatemia (28).

\section{REFERENCES}

1. Pollock DJ. The liver in coeliac disease. Histopathology 1977;1:421-30.

2. Hagander B, Brandt L, Sjolund K, Berg NO, Norden A, Stenstam M. Hepatic injury in adult coeliac disease. Lancet 1977;ii:270-2.

3. Jacobsen MB, Fausa O, Elgjo K, Schrumpf E. Hepatic lesions in adult coeliac disease. Scand J Gastroenterol 1990;25:656-62.

4. Iliffe GD, Owen DA. An association between primary biliary cirrhosis and coeliac disease. Dig Dis Sci 1979;24:802-6.

5. Freeman HJ. Celiac disease associated with primary biliary cirrhosis in a Coast Salish native. Can J Gastroenterol 1994;8:105-7.

6. Hay JE, Wiesner RH, Shorter RG, LaRusso NF, Baldus WP. Primary sclerosing cholangitis and celiac disease. A novel association. Ann Intern Med 1988;109:713-7.

7. Freeman HJ. Occult celiac disease associated with lymphocytic sclerosing cholangitis. Can J Gastroenterol 1994;8:249-52.

8. Wolber R, Owen D, DelBuono L, Appelman H, Freeman HJ. Lymphocytic gastritis in patients with celiac sprue or sprue-like intestinal disease. Gastroenterology 1990;98:310-5.

9. Wolber R, Owen D, Freeman HJ. Colonic lymphocytosis in patients with celiac sprue. Hum Pathol 1990;21:1092-6.

10. Alpert LI, Jindrak K. Idiopathic retroperitoneal fibrosis and sclerosing cholangitis associated with reticulum cell sarcoma. Gastroenterology 1972;62:111-7.

11. Harris OD, Cooke WT, Thompson H, Waterhouse JAH. Malignancy in adult coeliac disease and idiopathic steatorrhea. Am J Med 1967;42:899-912.

12. Logan RFA, Rifkind EA, Turner ID, Ferguson A. Mortality in celiac disease. Gastroenterology 1989;97:265-71

13. Freeman HJ, Weinstein WM, Shnitka TK, Piercey JRA, Wensel RH. Primary abdominal lymphoma. Presenting manifestation of celiac sprue or complicating dermatitis herpetiformis. Am J Med 1977;63:585-94.

14. Freeman HJ. Neoplastic disorders in 100 patients with celiac disease. Can J Gastroenterol 1996;10:163-6.

15. Colin R, Hemet J, Geffroy Y. Atrophie villositaire primitive. Cavitation ganglionnaire mesenterique. Atrophie splenique. Arch Fr Mal Appar Dig 1972;61:451-62.

16. Marche C, Bocquet L, Mignon M, Preel JL. Syndrome de malabsorption avec cavitation ganglionnaire mesenterique et atrophie splenique. Sem Hop Paris 1974;50:879-86.

17. Hoang C, Galian A, Maitre F, Degois T, Celerier M, Modigliani R.

\section{CONCLUSIONS}

The patient we described had celiac disease and progressive liver dysfunction due to a malignant lymphoma widely infiltrating the hepatic sinusoids. Histological studies of the liver also revealed multiple necrotizing punched-out foci, but studies for an infectious cause were negative. Splenic hypofunction with widespread necrotic changes in the spleen and mesenteric lymph nodes were reminiscent of the mesenteric lymph node cavitation syndrome. Postmortem studies showed a rare peripheral $\mathrm{T}$ cell lymphoma, other than an intestinal type, that was localized to liver, spleen and lymph nodes, but not small bowel, and most typical of hepatosplenic $T$ cell lymphoma, a variant with $T$ cell receptor rearrangement.

ACKNOWLEDGEMENTS: The author is grateful to Dr Jo-Ann Andriko, Hematopathology, Armed Forces Institute of Pathology, Washington, DC, for review of postmortem materials and immunohistochemical studies with CD3, L26 and CD34.

Atrophie villositaire totale. Cavitation ganglionnaire mesenterique, atrophie splenique. Forme particuliere de la maladie coelique de l'adulte, a propos d'un nouveau cas. Ann Pathol 1983;3:251-6.

18. Freeman HJ, Chiu BK. Small bowel malignant lymphoma complicating celiac sprue and the mesenteric lymph node cavitation syndrome. Gastroenterology 1986;90:2008-12.

19. Ishak KG, Rogers WA. Cryptogenic acute cholangitis - association with toxic shock syndrome. Am J Clin Pathol 1981;76:619-26.

20. Colby TV, LaBrecque DR. Lymphoreticular malignancy presenting as fulminant hepatic disease. Gastroenterology 1982;82:339-45.

21. Perera DR, Weinstein WM, Rubin CE. Small intestinal biopsy. Hum Pathol 1975;6:157-217.

22. Sacks S, Freeman HJ. Cytomegalovirus hepatitis: evidence for direct hepatic viral infection using monoclonal antibodies. Gastroenterology 1984;86:346-50.

23. Harris NL, Jaffe ES, Stein H, et al. A revised European-American classification of lymphoid neoplasms: a proposal from the International Lymphoma Study Group. Blood 1994;84:1361-92.

24. Farcet J, Gaulard P, Marolleau J, et al. Hepatosplenic T-cell lymphoma: sinusal/sinusoidal localization of malignant cells expressing the T-cell receptor gamma-delta. Blood 1990;75:2213.

25. Coiffier B, Brousse N, Peuchmaur M, et al. Peripheral T-cell lymphomas have a worse prognosis than B-cell lymphomas: A prospective study of 361 immunophenotyped patients treated with the LNK-84 regimen. Ann Oncol 1990;1:45.

26. Isaacson PG, O'Connor NTJ, Spencer J, et al. Malignant histiocytosis of the intestine: a T-cell lymphoma. Lancet 1985;ii:688-91.

27. Strayer DS, Reppun TS, Levin M, Deschryver-Kecskemeti K. Primary lymphoma of the liver. Gastroenterology 1980;78:1571-6

28. Zafrani ES, Leclercq B, Vernant J-P, Pinaudeau Y, Chomette G, Dhumeaux D. Massive blastic infiltration of the liver: a cause of fulminant hepatic failure. Hepatology 1983;3:428-32.

29. Freeman HJ, Seal AM. Survival from primary abdominal lymphoma presenting as a mass and obstructive jaundice. Can J Gastroenterol 1996;10:89-92.

30. Marsh GW, Stewart JS. Splenic function in adult coeliac disease. Br J Haematol 1970;19:445-57.

31. O'Grady JG, Stevens FM, Harding B, O'Gorman TA, McNicholl B, McCarthy CF. Hyposplenism and gluten-sensitive enteropathy. Natural history, incidence and relationship to diet and small bowel morphology. Gastroenterology 1984;87:1326-31. 


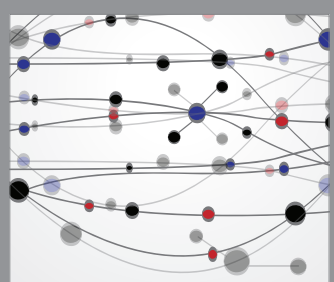

The Scientific World Journal
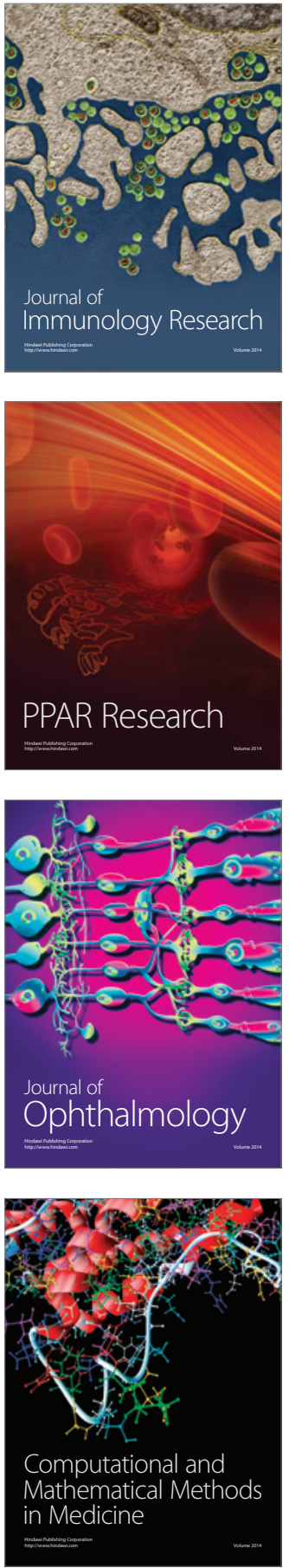

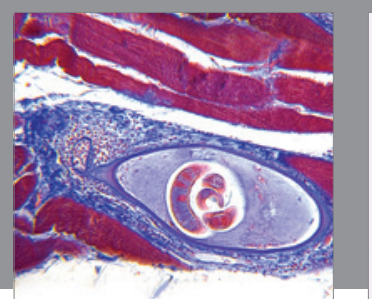

Gastroenterology Research and Practice

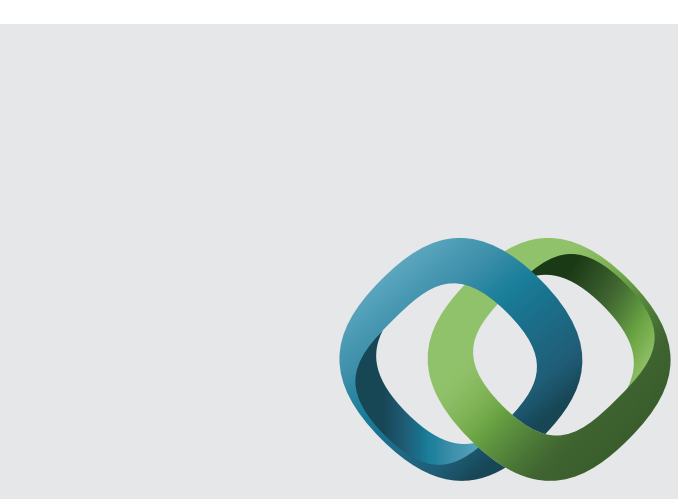

\section{Hindawi}

Submit your manuscripts at

http://www.hindawi.com
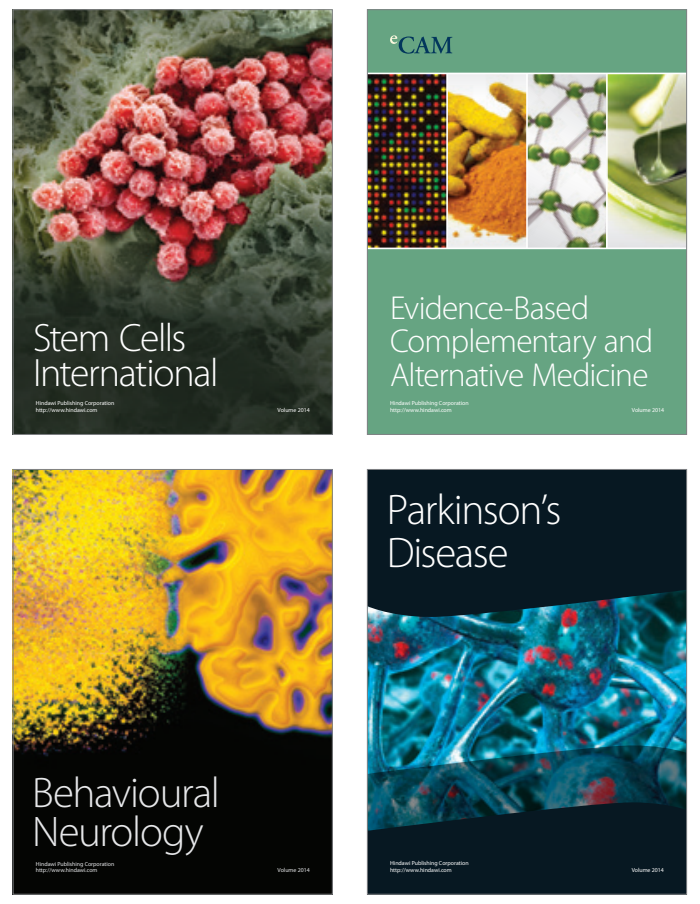
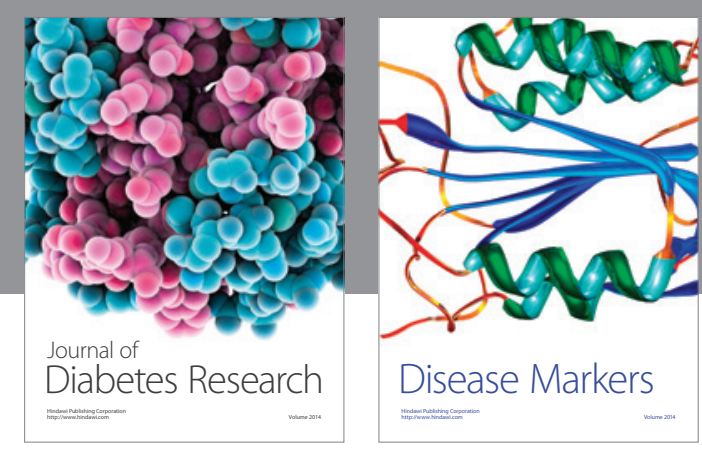

Disease Markers
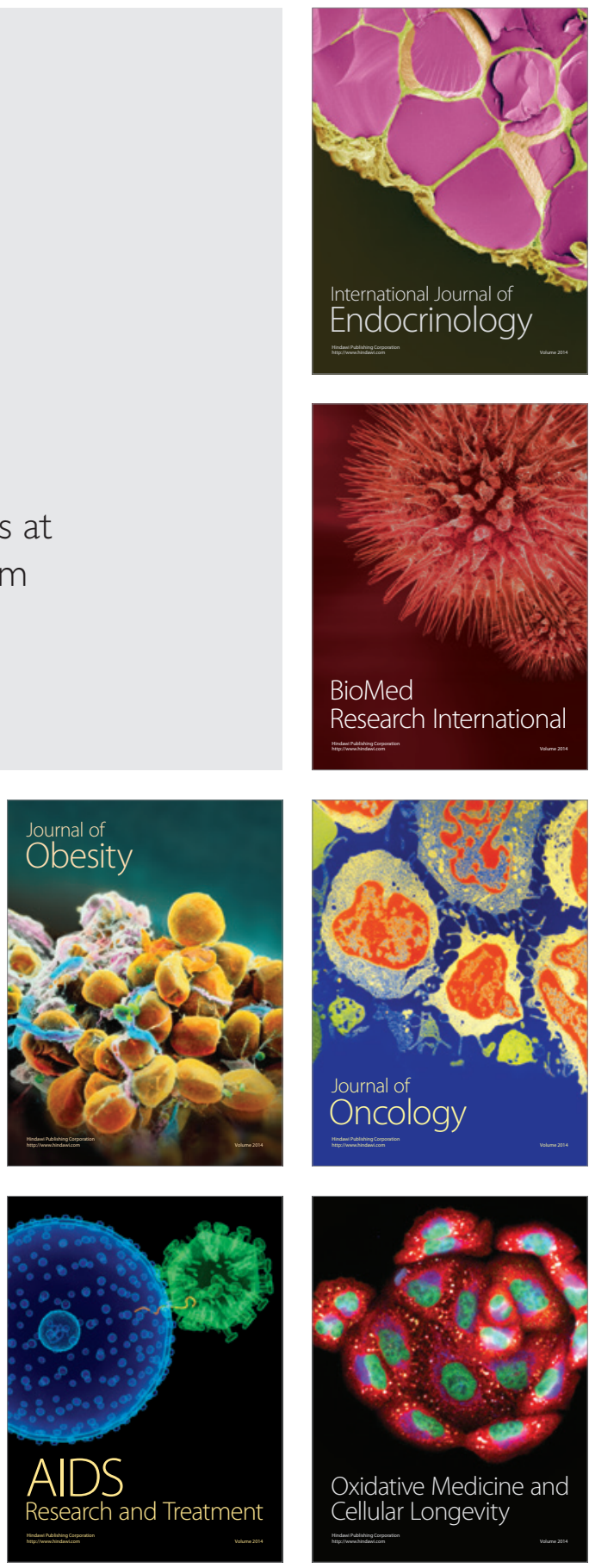